видавничий відділ Кам’янець-Подільского педінституту, 1996. - 152 с.

\title{
ДОСВІД ОРГАНІЗАЦЇ̈ ДОСЛІДНОЇ РОБОТИ У ШКОЛАХ УКРАЇНИ У ДРУГІЙ ПОЛОВИНІ ХХ СТОЛІТТЯ
}

Ірза В. І. Досвід організації дослідної роботи у школах України у другій половині ХХ століття.

У статті здійснено ретроспективний аналіз педагогічного досвіду організації дослідної роботи у загальноосвітніх школах України у 1945-1991 рр. Розглянуто методику проведення дослідів на навчально-дослідних ділянках шкіл. Висвітлено особливості організації дослідної роботи учнів у різних регіонах України в зазначений період.

Ключові слова: дослід, дослідна робота, спостереження, навчально-дослідна ділянка, сільськогосподарське дослідництво.

Ирза В. И. Опыт организации исследовательской работы в школах Украины во второй половине XX века.

В статье осуществлен ретроспективный анализ педагогического опыта организации исследовательской работы в общеобразовательных школах Украины в 1945-1991 гг. Изучена методика проведения опытов на учебно-опытных участках школ. Раскрыты особенности организации опытной работы учеников в разных регионах Украины в указанный период.

Ключевые слова: опыт, исследовательская работа, наблюдение, учебно-опытный участок, сельскохозяйственное опытничество.

Irza V. I. The experience of organization of research work at Ukrainian secondary schools in the second half of the twentieth century.

The article deals with the retrospective analysis of existing pedagogical experience of organization of research work at Ukrainian secondary schools during the period 1945-1991. It is spoken in detail about the technique of experiments at the teaching-experimental plot of the school. The features of the organization of research work of pupils in different regions of Ukraine are described.

Key words: experiment, research work, observation, teaching-experimental plot, agricultural research.

Протягом останніх десятиліть у нашій країні відбуваються значні соціальнополітичні, економічні та культурні процеси, які, у свою чергу, визначають принципово нові пріоритети розвитку системи освіти і вимоги до рівня підготовки учнів. 3 огляду на це однією 3 важливих і складних проблем педагогіки середньої школи $є$ організація дослідницької діяльності учнів як основної умови успішного функціонування навчального процесу, стимулу до активної навчально-пізнавальної діяльності молоді.

Одним із шляхів розв'язання зазначеної проблеми є глибоке осмислення й усвідомлення історико-педагогічного досвіду організації дослідної роботи учнів у загальноосвітніх школах України. Період другої половини ХХ століття викликає особливий інтерес, оскільки в цей час відбулися суттєві зміни та перетворення у галузі української освіти та виховання, зокрема в питаннях упровадження дослідної роботи як методу навчання в загальноосвітні навчальні заклади. 
Проблема організації дослідної роботи учнів, розвитку дослідницьких умінь школярів постійно привертала увагу педагогів, психологів, методистів. Шляхи i можливості використання дослідної роботи учнів у навчальному процесі аналізували у своїх роботах М. Алексєєв, І. Лернер, Л. Ляшко, О. Матюшкін, О. Обухов, А. Плігін, М. Скаткін та інші науковці.

У низці досліджень визначені вимоги до планування, організації та здійснення дослідної роботи в інноваційній школі (Т. Наливайко); розглянуті наукові і практичні задачі, які розв'язує педагогічний колектив у процесі дослідницької діяльності (Ю. Бабанський, В. Краєвський, О. Кузибецький, О. Овчиннікова), організаційнопедагогічні основи підготовки керівників загальноосвітніх навчальних закладів до проведення дослідної роботи (Ф. Ковкіна).

Різні аспекти організації дослідної роботи школярів досліджували вітчизняні науковці Н. Бібік, С. Гончаренко, Н. Захарова, І. Зязюн, О. Киричук, I. Кравцова,Н. Коваль, О. Ярошенко. Деяким питанням організації дослідної роботи школярів присвячені також дисертаційні праці Н. Бочарової, Д. Захарової, О. Кравчук, О. Марченко, С. Михайличенка, Н. Недодатко, О. Павленко, В. Самохіної та інших науковців.

Проте, незважаючи на значну кількість досліджень 3 питань організації дослідної роботи учнів, певні аспекти іiі впровадження в загальноосвітні навчальні заклади залишаються недостатньо вивченими.

Метою статті є ретроспективний аналіз педагогічного досвіду організації дослідної роботи в загальноосвітніх школах України у 1945-1991 pp.

На рубежі 40-50-х рр. ХХ ст. посилилася увага до вивчення природничих предметів, активізувалися пошуки найбільш оптимальних умов для розвитку пізнавальних інтересів та дослідницьких здібностей школярів. Дослідницький підхід став масовим у загальноосвітніх школах. У грудні 1958 р. Верховна Рада СРСР ухвалила Закон «Об укреплении связи школы с жизнью и о дальнейшем развитии системы народного образования в СССР», у якому особлива увага приділялася широкому розвитку у школах сільськогосподарського дослідництва.

Отже, проаналізуємо досвід організації дослідної роботи в окремих школах України у другій половині ХХ століття.

У 1947-1948 навчальному році 3 ініціативи викладача біології Ф. Пенчева у Лантратівській семирічній школі Троїцького району Луганської області був організований гурток юних натуралістів-мічурінців. Учні проводили велику за обсягом дослідну роботу на пришкільній ділянці і в біологічному кабінеті. Ця робота допомагала школярам розширити і поглибити свої знання 3 біології i набути практичні навички в галузі сільського господарства. Гурток з перших днів свого існування став привертати увагу учнів і до кінця 1950-1951 навчального року він налічував 63 юннати [7, с. 5].

Практика Лантратівської середньої школи показала, що проведення навчальних дослідів на ділянці слід доручати не одному учневі, а ланці, що складається 3 4-6 учнів. Робота всією ланкою надає впевненості в успіху навіть малоініціативним учням.

Ланки організовували з учнів V-VII класів. Учнів об'єднували в ланки за територіальним принципом, ураховуючи їх місце проживання. Ланкових обирали самі учні. Кожний учень знав, що ланка повинна працювати на ділянці тричі на місяць в позаурочний час.

Учителі контролювали роботу новоорганізованих ланок: нагадували про розклад роботи, пропонували цікаві завдання, підбадьорювали дітей, заохочували найкращих. 
Кожна ланка отримувала конкретне завдання, наприклад: полити рослини в теплиці, зібрати колекцію листків або насіння бур'янів, поставити дослід, передбачений програмою з ботаніки, прочитати матеріал про рослину, 3 якою ланка закладатиме дослід на ділянці тощо.

На початку кожного уроку в V-VI класах 2-3 хвилини вчитель приділяв повідомленню про те, яку роботу виконали ланки за тиждень, підкреслював значення цієї роботи, відзначав найактивніших учнів. Це сприяло формуванню в учнів відчуття значущості своєї роботи, стимулювало до подальшої плідної діяльності.

Перш ніж приступити до дослідної роботи, кожний учень повинен був знати мету роботи, найважливіші біологічні особливості вирощуваної рослини, строки виконання окремих видів робіт, методику проведення фенологічних спостережень та очікувані результати. Без цих даних робота учнів не була б осмисленою і втратила б свою цінність.

Для того щоб учні здійснювали дослідну роботу свідомо, вчителі задовго до початку весняних польових робіт проводили заняття в гуртках і ланках, індивідуальні бесіди $з$ учнями. Така діяльність сприяла своєчасному і доброякісному проведенню дослідних робіт на ділянці. Задля підготовки учнів до проведення дослідів вчителі складали докладні інструкції, які містили всі відомості, необхідні учням для виконання робіт на ділянці. Учні переписували зміст інструкції і використовували наявні в ній відомості у своїй практичній роботі. Складені інструкції кожного року передавалися 3 класу в клас.

Учні вели фенологічні спостереження за розвитком рослин, проводили всі агротехнічні заходи i здійснювали боротьбу зі шкідниками та хворобами сільськогосподарських рослин. Для проведення фенологічних спостережень вчителі розробили схеми за окремими групами рослин і пропонували учням переписати їх у свої щоденники [4, с. 4].

Для більшої точності окремі досліди закладали у двох-трьох повтореннях.

Досвід роботи Лантратівської середньої школи показав, що при такій системі роботи на навчально-дослідній ділянці більшість учнів успішно засвоювала всі процеси проведення сільськогосподарських дослідів і впевнено виконувала різні роботи. Учні на практиці опановували складні прийоми щеплення рослин, вирощування сіянців, штучного запилення, обробітку грунту тощо.

Значну дослідну роботу проводили учні Середньої школи № 7 м. Ужгорода Закарпатської області. Навчально-дослідна ділянка школи мала два відділи ботаніко-рослинницький площею 0,33 га, що складався 3 теплично-парникового господарства, оранжереї, квітників та парку і зоолого-тваринницький відділ, що складався 3 крільчатника та живого куточка 3 акваріумами, тераріумом і вольєрою 3 хвилястими папугами.

В оранжереї було створено 3 відділи-секції: секцію розведення рослин 3 підсекціями кімнатних i грунтових рослин, секцію овочевих культур і секцію квітництва. Кожна секція працювала за певним режимом. На спеціально опалюваній частині стелажа були створені умови температури і вологості для вкорінення живців декоративних рослин. Для теплолюбних рослин було зроблено маленьку тепличку. На центральному стелажі 3 меншим обігріванням вирощували овочі, розміщували кімнатні рослини.

Після введення в дію оранжереї серед учнів провели збір кімнатних рослин, живців кімнатних і декоративних рослин-кущів. Це відразу дало можливість організувати роботу всіх учнів 3 вегетативного розмноження рослин. Були 
використані зелені живці самшиту, листкові живці бегонії рекс, живці фікуса, монстери, гортензії, клематиса, гліцинії, роз, хризантем, форзиції, японської айви та багатьох інших рослин. Наприкінці навчального року було зібрано колекцію кімнатних рослин понад 30 видів. Розпочато роботу по догляду за кімнатними рослинами. Усі учні, в порядку чергування, мили, обприскували, підживлювали і пересаджували кімнатні рослини [5, с. 10].

Робота в теплично-парниковому господарстві школи проводилася в трьох напрямках: вирощування декоративних рослин для потреб школи та реалізації; вирощування розсади овочевих і декоративних рослин-літників для потреб школи та реалізації і проведення дослідної роботи з декоративними рослинами.

Роботу було організовано так, щоб усі учні школи брали участь в усіх видах робіт теплично-парникового господарства. Задля цього учнів V-IX класів об'єднували в ланки по 5-6 школярів. Кожній ланці доручалося виконувати певну роботу від початку до кінця, наприклад, вигонку гортензії, вигонку глоксинії, укорінення живців самшиту для живої огорожі школи тощо. Крім того, члени кожної ланки брали участь в усіх видах трудомістких і масових робіт - заготівлі грунту, добрив, ремонтуванні теплиць. Учні вчилися проводити тривалі спостереження, доводити почату справу до кінця, проводили роботи, необхідні для всього циклу робіт у закритому грунті.

Для того щоб усі члени ланки могли набути певних навичок і вмінь, роботу проводили 3 великою кількістю рослин. Наприклад, ланка, яка дістала завдання виростити гортензію, повинна була довести до цвітіння не менше як 200 рослин; ланка, яка вирощувала самшит для зеленої огорожі, мала на меті укорінити 600 живців самшиту.

Роботу з ланками організовували в такий спосіб: по можливості задовольняли інтерес учнів у виборі об'єкта роботи, потім ланка отримувала конкретне завдання. Одночасно із завданням надавали короткий інструктаж з вирощування певної рослини і приблизний план. На основі інструктажу складали докладний план роботи учнів. Роботу проводили під час уроків і в позаурочний час за спеціально створеним розкладом.

Крім навчальної і масової роботи 3 розведення декоративних рослин для озеленення школи і шкільної садиби, в оранжереї також здійснювали дослідну роботу. Група юннатів проводила зимню вигонку конвалії, виконувала роботу щодо вигону квітучих хризантем протягом усього року живцюванням. Упливом короткого дня учні досягли цвітіння гладіолусів у травні. Вирощування примул, цикламена і глоксинії дало можливість організувати роботу по схрещуванню цих рослин. Для того щоб мати насіння кращої якості, проводили насінницьку роботу: відбирали найкращі рослини, запилювали тільки перші 2- 3 квітки, створюючи умови для росту і розвитку рослин.

Паралельно 3 роботою 3 вегетативного розмноження рослин учні ставили досліди 3 вивчення найкращих строків живцювання гортензії живцями зеленими, здерев'янілими, вкритими листям, без листя.

У результаті роботи учнів у тепличному господарстві у школі було створено колекцію кімнатних рослин близько 1500 штук, розарій, який налічував понад 300 кущів роз, у парку школи було висаджено понад 100 кущів грунтової гортензії та інших декоративних рослин. Це допомогло не тільки прищепити учням навички i вміння до роботи в закритому грунті, а й зробити викладання біології цікавішим, предметним, оснащеним живим матеріалом протягом усього навчального року, що позитивно вплинуло на якість знань учнів.

Розглянемо досвід організації дослідної роботи у Васильківській середній школі 
№ 3 Київської області. Навчально-дослідну ділянку в цій школі використовували 3 навчально-виховною метою. На ній проводили практично-дослідну роботу з учнями 1-4 класів, визначену програмою для початкових класів, організовували практичні заняття і літню практику з учнями середніх і старших класів, закладали досліди 3 вивчення впливу різних агрозаходів на врожайність рослин, працювали над сортовивченням, гібридизацією рослин тощо.

Шкільна навчально-дослідна ділянка слугувала базою заготовлення дидактичного матеріалу для практичних занять, поповнення біологічного кабінету. Роботу на навчально-дослідній ділянці планували відповідно до програми з біології та завдань, які стояли перед тогочасною школою. Ураховуючи зміст навчальної програми і специфіку свого району, вчителі та учні складали виробничий план праці учнівського колективу на шкільній ділянці. У виробничому плані вказували розмір полів сівозмін, центральних доріжок і доріжок між ділянками. Виробничий план затверджувався на засіданні педагогічної ради.

Практика роботи у Васильківській середній школі показала, що від того, як спрямовано дитячий колектив на виконання дослідів, практичних робіт, залежатиме діяльність учнів протягом року й особливо в літній період. Для цього в школі заздалегідь планували всю роботу з організації навчально-дослідної ділянки, доводили завдання до кожного класу, ланки, окремих учнів. На початку навчального року для роботи на дослідній ділянці розподіляли учнів на ланки, які обирали ланкових.

Роботу на шкільній ділянці включали в план виховної роботи класних керівників, а також піонерської і комсомольської організацій.

Підготовчу роботу до проведення дослідів розпочинали на уроках ботаніки, а продовжували на уроках праці. На одному з уроків проводили бесіду про зміст і завдання дослідів, про їх значення під час вивчення ботаніки і зв’язок з сільським господарством. Учням розповідали, як потрібно вести дослідження і фіксувати їх у щоденниках. Задля мотивації навчально-дослідної діяльності учнів на початку кожного навчального року у школі проводили Свято врожаю, на якому підводили підсумки роботи учнів на навчально-дослідній ділянці. На цьому святі дирекція школи відзначала і нагороджувала ланки і окремих учнів, які досягли успіхів у проведенні своїх дослідів.

Земельну площу ділянки розподіляли між класами і ланками відповідно до дослідів і розміщували таблички, на яких вказували назву культури й досліду, клас, прізвище ланкового [1, с. 35].

Усі навчальні досліди учні закладали під час практичних занять.

Учні IV класів закладали дослід з вивчення впливу різних способів передпосівної підготовки насіння на врожай овочевих культур. Одна ланка обігрівала насіння, друга пророщувала його, третя - яровизувала, четверта проводила посів добірним насінням.

Учні V класів досліджували вплив строків посіву зернових культур на врожай. Кожна ланка висівала насіння кукурудзи в певний строк. Наприклад, ланка №1 проводила посів 1 квітня, ланка №2 - 15 квітня тощо. Учні закладали також досліди про вплив різних добрив на врожай польових культур. Наприклад, у досліді 3 кукурудзою перша ланка вдобрювала грунт під кукурудзу органічними добривами, друга - органо-мінеральними, третя - гранульованими, четверта - вирощувала кукурудзу без добрив.

Завершивши дослід, ланки разом підводили підсумки: бачили результати впливу добрив на врожай. Отже, всі учні $\mathrm{V}$ класів були охоплені дослідною роботою. На початку навчального року на уроках ботаніки школярі (уже VI класу) розповідали про 
результати роботи [3, с. 67].

Під час проведення досліду учні порівнювали рослини 3 контрольними i переконувалися, що без спостережень вони не встановили б, який уплив на рослини має вдобрення грунту, підживлення тощо. Догляд за рослинами і спостереження учні вели позаурочно за підготовленим планом. Користуючись цим планом, учні без труднощів проводили спостереження і записували у своїх щоденниках їх результати.

Така організація проведення дослідів на навчально-дослідній ділянці давала можливість охопити роботою всіх учнів і мала позитивні результати в засвоєнні ними теоретичного матеріалу і набуванні практичних умінь.

Вивчення досвіду організації дослідної роботи в українській загальноосвітній школі у другій половині XX ст. показало, що дослідна робота використовувалась переважно для підвищення якості знань з предметів біологічного циклу (ботаніки, зоологіі), основ сільськогосподарського виробництва, була спрямована на зміцнення зв'язку навчання $з$ трудовою діяльністю учнів, охоплювала навчальний, позакласний i позашкільний час і мала навчальну, виробничу і наукову значущість. Нині необхідно критично переосмислити наявний педагогічний досвід, адже раціональне використання доробку наших попередників сприятиме розбудові загальноосвітньої школи. Надбання минулого доцільно наповнити сучасним науковим змістом, обрати ті шляхи та форми організації дослідної роботи, які сприятимуть удосконаленню навчально-виховного процесу і допомагатимуть виходу України на світовий рівень у галузі освіти і науки.

До перспектив подальших розвідок в окресленому напрямі слід віднести вивчення особливостей організації дослідної роботи в загальноосвітній школі у незалежній Україні.

\section{Література}

1. Денисюк О. Л. Навчально-дослідна робота учнів у шкільному саду / О. Л. Денисюк. - К. : Рад. школа, 1960. - 104 с. 2. Дослідницька робота в школі / [упоряд. У. А. Тюпа, Є. Д. Видро, Н. М. Шаповал; за ред. У. А. Тюпи]. К. :Рад. школа, 1962. - 132 с. З. Методика и тематика опытнической работы кружков юных натуралистов и ученических учебно-производственных бригад/[сост. К. Ф. Руденко, А. М. Шерман, Д. А. Яковлев]. - Луганск, 1960. - 42 с. 4. Організація дослідницької роботи з зерновими культурами в школі / [упоряд. М. Я. Ліцовський, С. А. Клименко]. - К. : Рад. школа, 1965. - 14 с. 5. Процик И. И. Формирование исследовательских умений и навыков у учащихся сельской школы : дис. ... канд. пед. наук / Иван Игнатьевич Процик. - К., 1977. - 164 с. 6. Учебно-опытная работа юных натуралистов-мичуринцев (из опыта работы кружка юннатов Лантратовской семилетней школы Троицкого района)/[упоряд. Ф. Ф. Пенчев]. - Ворошиловград, 1952. -42 c.

\section{УПРОВАДЖЕННЯ ВЕРБАЛЬНО-ГРАФГЧНИХ МЕТОДІВ НАВЧАННЯ У ПЕДАГОГІЧНІЙ СПАДЩИНІ С. ШЕВЧЕНКА}

Москальова О. I. Упровадження вербально-графічних методів навчання у педагогічній спадщині С. Шевченка.

У статті досліджено й узагальнено досвід вітчизняного педагога-новатора С. Шевченка щодо розроблення теоретичних засад та впровадження вербальнографічних методів навчання. Проаналізовано позитивні сторони використання структурно-логічних схем на різних етапах навчального процесу, підкреслено доцільність їх подальшого вдосконалення та використання у навчально-виховному 